\title{
Analysis Of The Effect Of Bending Strength On Scaffolding System With Direct Analysis Method
}

\author{
Michael Talim \\ Department Of Civil Engineering, University Of North Sumatra, Jl. Dr. Mansur No. 9 Padang Bulan, Kec. \\ Medan Baru, Kota Medan 20222
}

\begin{tabular}{|c|c|}
\hline ARTICLE INFO & ABSTRACT \\
\hline Article history: & \multirow{4}{*}{$\begin{array}{l}\text { Steel scaffolding is a very important component in formwork work to } \\
\text { support further work. The purpose of this analysis is to review the } \\
\text { maximum compressive strength that occurs in 3-story scaffolding } \\
\text { before buckling occurs using the direct analysis method (DAM). The } \\
\text { design of steel structures, which are generally slender, requires } \\
\text { stability analysis. The result is influenced by imperfections (non- } \\
\text { linear geometry) and inelastic conditions (non-linear material). In this } \\
\text { final project, we use second-order inelastic analysis based on direct } \\
\text { analysis method. The 3-level scaffolding model was analyzed using } \\
\text { beam elements in the SAP2000 program with } 6 \text { variations of notional } \\
\text { loads applied to the weak axis direction of the scaffolding pipe. The } \\
\text { lowest compressive strength on 3-story scaffolding before buckling } \\
\text { occurs is } 18.24 \text { kN with horizontal notional loads to the right on the } \\
\text { first level scaffolding, left on the second level scaffolding and to the } \\
\text { right on the 3rd level scaffolding. The results of the analysis show } \\
\text { that the maximum compressive strength obtained results in a large } \\
\text { displacement drastically in the iteration step. By using the analysis } \\
\text { on the DAM methed the results obtained are more effective }\end{array}$} \\
\hline $\begin{array}{r}\text { Received Aug 08, } 2021 \\
\text { Revised Sep 18, } 2021 \\
\text { Accepted Oct 30, } 2021\end{array}$ & \\
\hline Keywords: & \\
\hline $\begin{array}{r}\text { Scaffolding } \\
\text { Direct Analysis } \\
\text { Compressive Strength } \\
\text { Steel } \\
\text { National Loads }\end{array}$ & \\
\hline
\end{tabular}

This is an open access article under the CC BY-NC license.

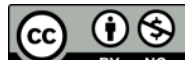

\section{Corresponding Author:}

Michael Talim,

Department Civil Engineering,

University Of North Sumatra,

Jl. Dr. Mansur No. 9 Padang Bulan, Kec. Medan Baru, Kota Medan 20222.

Email : michaeltalim@gmail.com

\section{INTRODUCTION}

Nowadays, there are many project developments in big cities such as the construction of hotels, apartments, housing and others. The very rapid development of science and technology has affected the progress of the industrial and business world today. This is proven by the large number of large companies. and small businesses that compete to produce quality products using super-sophisticated equipment.

Scaffolding is a temporary structure used to support people and materials in the construction or repair of buildings and other large structures. Scaffolding is usually in the form of a modular system of metal pipes or tubes, although other materials can also be used. In some Asian countries such as China and Indonesia, bamboo is still used as a scaffold. But the majority of construction workers now use scaffolds made of iron.

One of the important components in working on the structure of a project in construction is scaffolding because this component is used from the beginning to the end of the project as a 
support material that must be used in all construction activities to protect workers in the construction sector. attention to contractors.

In Indonesia itself, the implementation of construction has caused many general problems in the field of occupational health and safety. This is very worrying and even dangerous for the workers who do the work because every day workers have to climb the scaffolding even when working to renovate the building. safety aspects of the scaffolding used must truly noticed good on Step installation, use or disassembly.

There is also a system in scaffolding called shoring and reshoring wherein, shoring is a component present on a scaffold such as horizontal, vertical or inclined girders where metallic components are assembled into modular units that can be strung on top of each other, to form a series of towers consisting of from the system of vertical load bearing beams. The shoring system is very helpful for workers and fresh concrete on the top floor. Shore also distributes the load from above to the bottom of the floor slab which is a surface rather than a reshore.

While reshoring is a system designed to overcome problems related to concrete that has a heavy load. Usually for concrete floors, the dead load is greater than the live load. If we only depend on the live load capacity of the floor only to support the load of workers and concrete which will be used for construction from above, it will be overweight on the floor slab. The reshore system consists of three or more floor slabs separated between floors. The slabs and interfloor reshores behave as an integrated structural system to support the interfloor shore loads. The reshore helps prevent cracking of the former slab.

\section{RESEARCH METHOD}

The research method used in this final project is the literature method where the data required is based on specifications in the field and related research.

The results of the buckling strength analysis on the 3-story scaffolding model will be reviewed against several conditions to obtain the maximum compressive strength that occurs.

\subsection{Determining Parameter of Steel Structure Stability}

If we study the compression member design parameters which have taken into account the material strength ( $\mathrm{Fy}$ ) and stability (buckling), it is easy to see that the compressive strength is determined by the parameters $\mathrm{E}, \mathrm{Fy}, \mathrm{KL} / \mathrm{r}$ and $\mathrm{Ag}$. The first two refer to the material, while the last two refer to its geometric state. It turns out that after a more in-depth study, these parameters are not the main factor. It will only match if it is related to the formula or capacity curve contained in the code that uses these parameters (Galambos 1998, Salmon et.al 2009).

This parameter was chosen as an accurate strategy for simplifying the solution to predict the nominal strength of the compression rod. Although the parameters look simple but in certain cases it is proven to provide a satisfactory correlation to the empirical test data. This simplification strategy is necessary because during the preparation of the formula and its completion, the use of computers was not yet popular in the community. Generally it still depends on how to solve manually with a calculator.

\section{RESULTS AND DISCUSSIONS}

\subsection{Scaffolding Specifications}

In this study, the size and shape of the scaffolding that will be used for the analysis of the DAM method are:

a. $\quad$ Pipe diameter $=48.3$

b. $\mathrm{mm}$ Thickness of pipe $=2$

c. $\mathrm{mm}$ Bending length of pipe $=1220$

d. $\mathrm{mm}$ Pipe inertia $=78098 \mathrm{~mm} 4$

e. Radius of pipe $=16,3848$

f. $\quad \mathrm{mm}$ Mutu steel $=240 \mathrm{Mpa}$

g. Scaffolding Height $=5100$

h. $\mathrm{mm}$ Scaffolding Width $=1219 \mathrm{~mm}$ 


\subsection{Strong press nominal}

Global buckling is determined by the slenderness of the cross-sectional element and its shape. Global or local buckling depends on the classification of the cross-section, if the crosssection is not slender then there is no local buckling, and conversely the slender cross-section is at risk of local buckling first. The buckling that occurs in scaffolding is Flexural Bending (AISC). - E3).

\subsection{Analysis Model}

The 3-level scaffolding model was analyzed using beam elements in the SAP2000 program with 6 variations of notional loads applied to the direction of the weak axis of the scaffolding pipe. , $78 \mathrm{kN}$. Ni $=0.002(69.78)=0.14 \mathrm{Kn}$ Some variations of imperfection conditions reviewed in this study are shown in the figure below.

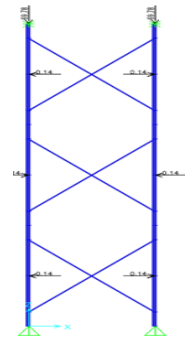

(d)

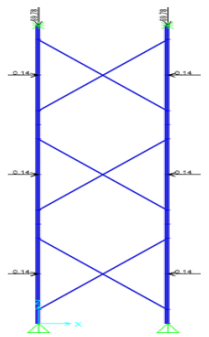

(e)

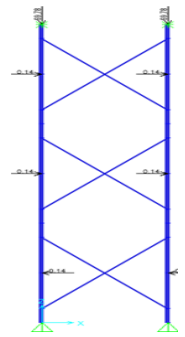

(f)

Figure 1. Model imperfections

The analysis was carried out using the nonlinear static analysis feature available in the SAP2000 structural analysis program in accordance with the provisions of using the direct analysis method to determine the critical compressive strength of the scaffolding pipe column before buckling occurs.

The results of the analysis that are reviewed are in the form of a graph of the force and displacement on one of the scaffolding pipes to review the critical load that is capable of being carried by the scaffolding with the imperfection conditions applied. The graphs between force and displacement for each model are shown as follows:

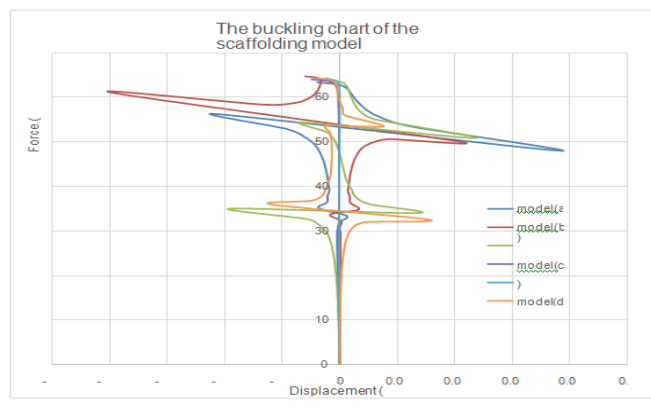

Figure 2. Scaffolding Model Graph

The critical buckling force for each imperfection model is tabulated as follows by reviewing the conditions where there is a large displacement drastically in the iteration step by the SAP2000 program as follows: 
Table 1. Compressive Strength Results

\begin{tabular}{cc}
\hline Model & $\operatorname{Pcr}(\mathrm{kN})$ \\
\hline $\mathrm{a}$ & 33.37 \\
$\mathrm{~b}$ & 33.75 \\
$\mathrm{c}$ & 18.24 \\
$\mathrm{~d}$ & 62.93 \\
$\mathrm{e}$ & 64.29 \\
$\mathrm{f}$ & 23.8 \\
\hline
\end{tabular}

Based on the results of the analysis by reviewing 6 structural imperfections, the lowest value of the compressive strength of scaffolding before buckling occurs is $18.24 \mathrm{kN}$ for 3 levels of scaffolding. The results of the analysis using the DAM method in this study are lower than the analysis using the ELM method.

\section{CONCLUSION}

The response of the structure is in the form of how much load is given until buckling occurs on the scaffolding system and the buckling strength resulting from buckling, then several conclusions can be drawn as follows: The results of the analysis using the DAM method show that the higher the level of scaffolding, the capacity of the scaffolding will decrease due to imperfections and inelasticity of the material. The smallest flexural strength value obtained before the buckling occurs is the imperfection $\mathrm{C}$ model with a compressive strength of $18.24 \mathrm{kN}$ The resulting flexural strength value affects the slender and non-slender sections based on the provisions of AISC-2010.

\section{REFERENCES}

AISC, Manual of Steel Construction, "Load and Resistance Factor Design," Americanlnstitute of Steel Construction, Chicago, IL, 2005.

Fransiska(2015), Analisis dan Desain /Perencanaan Struktur Scaffolding sebagai Alat Penyokong Bekisting Beton, Universitas Sumatera Utara, Indonesia.

Departemen Tenaga Kerja dan Transmigrasi RI. 2011. Peraturan Menteri TenagaKerja dan Transmigrasi No.PER-01/MEN/1980 tentangkeselamatandan kesehatan kerja konstruksi bangunan. Jakarta: Depnakertrans RI.

Trahair,N.S. 1993. Felxural-Torsional Buckling of Structures.Boca Raton, FL : CRC.

I.A. Rai Widhiawati, A.A.G.A. Yana, dan A.A. Asmara (2010), Analisa Biaya Pelaksanaan Antara Pelat Konvensional Dan Sistem Pelat Menggunakan Metal Deck, Universitas Udayana, Denpasar.

Dewobroto, Wiryanto. 2015."Struktur Baja - Perilaku,Analisis \& Desain - AISC 2010", Universitas Pelita Harapan, Tangerang.

PT. Gunanusa Utama Fabricators. 2010. Jenis dan Material Perancah. Jakarta

Ervianto, Wulfram I. 2006. Eksplorasi Teknologi Dalam Proyek Konstruksi ( Beton Pracetak Dan Bekisting). Yogyakarta : Andi Offset

Allen, H.G dan P.S. Bulson. 1980. Background to Buckling. McGraw Hill Book Company, U.K... Astaneh-Asl, A. 2002

John Enright, Robert Harriss, and Gregory J Hancock. 2000. "Stability of BracedScaffolding and Formwork with Spigot Joints". Journal. Fifteenth InternationalSpecialty Conference on Cold-Formed Steel Structures St.Louis, Missouri U.S.A. 